\title{
Extramedullary Hematopoiesis and Intratumoral Production of Cytokines in Childhood Hepatoblastoma
}

\author{
D. VON SCHWEINITZ, D. SCHMIDT, J. FUCHS, K. WELTE, AND T. PIETSCH \\ Departments of Pediatric Surgery [D.v.S., J.F.] and Pediatric Oncology/Hematology [K.W., T.P.], Medical \\ School Hannover, Hannover, Department of Pediatric Pathology, University of Kiel and Institute for \\ Pathology, Mannheim [D.S.], and Institute for Neuropathology [T.P.], Medical Center, University of \\ Bonn, Bonn, Germany
} \begin{abstract}
Extramedullary hematopoiesis is a characteristic feature of
hepatoblastoma (HB). We investigated $15 \mathrm{HB}$ to characterize intratumoral hematopoietic foci and to find clues to the pathophysiology of their formation. By conventional histology and immunohistochemistry, we found erythroblasts in all and megakaryocytes in 10 of the $\mathrm{HB}$, whereas granulocyte and monocyte precursor cells could not be identified in hematopoietic foci of any tumor. Only a minority of erythropoietic cells in these foci contained fetal $\mathrm{Hb}(\mathrm{HbF})$. We recently found that $\mathrm{HB}$ cells produce IL- $1 \beta$ and thus stimulate stromal cells to secrete IL-6. We therefore searched for other hematopoietic cytokines in $\mathrm{HB}$. Supernatants of primary HB cultures were subjected to ELISA, bioassayed, and immunoblotted. We detected erythropoietin (EPO) in 11 of 15 , stem cell factor (SCF) in 7 of 11 , granulocyte colony-stimulating factor (G-CSF) in 4 of 15 , granulocyte/ macrophage colony-stimulating factor (GM-CSF) in 6 of 15 , IL-3 in 1 of 12 , leukemia inhibitory factor (LIF) in 1 of 9 , and macrophage colony-stimulating factor (M-CSF) in 1 of 8 conditioned media. With immunoenzymatic labeling we localized EPO and SCF to the cytoplasm of epithelial HB cells, whereas
\end{abstract}

HB is a highly malignant epithelial neoplasm of the liver. It is the most common hepatic tumor of childhood and affects infants and children mostly in the first $3 y$ of life (1). According to the most widely used histologic classification of Ishak and Glunz (1), pure epithelial $\mathrm{Hb}$ are distinguished from mixed $\mathrm{Hb}$ containing both epithelial and mesenchymal components. The epithelial tumor components usually consist of areas resembling either embryonal or fetal liver. Mixed HB additionally contain mesenchymal tissue with foci of immature spindle cells, more mature fibrous septa, and osteoid $(1,2)$. Foci of

Received September 1, 1994; accepted April 13, 1995.

Correspondence and reprint requests: Dietrich von Schweinitz, M.D., Department of Pediatric Surgery, Medical School Hannover, Konstanty-Gutschow-Strasse 8, D-30625 Hannover, Germany.

Supported in part by the Gesellschaft der Freunde der Medizinischen Hochschule Hannover. stromal cells and cells of immature fibrous tissue of mixed $\mathrm{HB}$ expressed SCF, G-CSF, GM-CSF, LIF, and M-CSF. EPO and SCF could also be detected in extracts of epithelial HB cells. We conclude that, in HB, erythropoiesis and megakaryopoiesis but not the granulocyte-macrophage lineage is induced by fetal and embryonal tumor cells in cooperation with stromal cells by locally secreted cytokines. (Pediatr Res 38: 555-563, 1995)

HB, hepatoblastoma

EPO, erythropoietin

SCF stem cell factor

G-CSF, granulocyte colony-stimulating factor

GM-CSF, granulocyte/macrophage colony-stimulating factor

M-CSF, macrophage colony-stimulating factor

LIF, leukemia inhibitory factor

CD, cluster of differentiation (leukocyte typing)

$\mathbf{H b F}$, fetal $\mathrm{Hb}$

APAAP, alkaline phosphatase anti-alkaline phosphatase extramedullary hematopoiesis are a characteristic histologic feature of $\mathrm{HB}(1,2)$. They are consistently associated with fetal tumor areas (1) but also seem to occur in less differentiated embryonal tumor tissue (2). Histologically, they contain erythropoietic cells and sometimes megakaryocytes (2). The molecular pathomechanisms leading to extramedullary hematopoiesis in HB are still undefined. As in fetal liver (3) foci of hematopoiesis are often seen in tumor sinusoids, but can also be found in an intimate relationship with the tumor cells. This finding suggests that the microenvironment is more important for induction of hematopoiesis in HB than are humoral factors (4). EPO has been found in fetal liver tissue where it is important for fetal erythropoiesis (5), and it is produced by several hepatoma cell lines (6). The SCF was shown to be a mediator of differentiation and proliferation of hematopoietic cells in the fetal liver (7). In some patients, $\mathrm{HB}$ induce para- 
neoplastic thrombocytosis and rarely also polycythemia. In a recent investigation we found that $\mathrm{HB}$ cells can produce IL- $1 \beta$ and thereby stimulate the excretion of IL-6 in stromal cells, which seems to play a role in the elevation of the patients' platelets (8). Because neither IL-1 nor IL-6 are known to support erythropoiesis or megakaryopoiesis on their own, we now investigated whether other hematopoietic growth factors such as EPO, IL-3, G-CSF, GM-CSF, M-CSF (9), LIF (10), and SCF (11) occur in HB. We also studied whether hematopoietic cells other than erythroblasts or megakaryocytes are present in HB. Recently, we observed that human HB cells from a newly established cell line induce intratumoral hematopoiesis when xenografted in immunodeficient mice (our manuscript in preparation). This indicates that they are able to attract hematopoietic progenitor cells from the blood stream. We therefore searched for multipotential stem cells in the tumors and attempted to find further clues to their origin by determining the maturity of the intratumoral erythropoietic cells.

\section{METHODS}

Patients. Fifteen children aged 6-54 mo underwent laparotomy for excision of $\mathrm{HB}$. No patient had received preoperative chemotherapy. One case was a recurrent tumor 2 y after the first excision (patient 15). Tumors confined to one lobe of the liver were resected; more extensive ones were biopsied. After surgery all children received chemotherapy according to the protocol of the Pediatric Liver Tumor Study HB89 of the German Society for Pediatric Oncology and Hematology (12). Tumors not primarily excised were resected at second look surgery followed by adjuvant chemotherapy. Before treatment, blood cell counts were determined, and serum was drawn from all patients and stored at $-20^{\circ} \mathrm{C}$. Tumor material was transferred into cold RPMI 1640 medium (GIBCO, Berlin, Germany) under sterile conditions immediately after excision and maintained at $4^{\circ} \mathrm{C}$. For control of immunohistochemistry we used patients' normal liver tissue and fetal liver from a spontaneous abortion (26th gestational week). Informed consent was obtained from the parents of all patients.

Histologic preparations. Representative samples from all tumors were fixed in $3.5 \%$ formaldehyde and embedded in paraffin. Sections $(5 \mu \mathrm{m})$ were stained with hematoxylin/eosin, Giemsa, periodic acid-Schiff, Goldner, and Bielschowsky's reticulin stains. Histologically, the slides were examined for the distribution of epithelial and mesenchymal tumor components, the tumor cells' differentiation, and the occurrence of hematopoiesis. The tumors were classified as proposed by Ishak and Glunz (1). Adjacent pieces from the tumors were suspended in Hanks' balanced salt solution (GIBCO), snapfrozen, and stored at $-80^{\circ} \mathrm{C}$. Cryostat sections $(8 \mu \mathrm{m})$ were cut from these samples, dried, wrapped in aluminum foil, and stored at $-20^{\circ} \mathrm{C}$ until further use. Cryostat sections of each tumor as well as blood smears from a healthy adult and a 4-h-old premature newborn of the 29th gestational week fixed in 75\% ethanol for $5 \mathrm{~min}$ were stained for $\mathrm{HbF}$ using a commercially available staining kit (Sigma Chemical Co., Deisenhofen, Germany) with which the cells are treated with sodium citrate $(0.7 \mathrm{~mol} / \mathrm{L})$ before staining with hematoxylin/ eosin.

Cytologic preparations. Tumor pieces were minced, suspended in RPMI 1640 medium, and passed through a metal sieve. The cell suspensions were separated from debris by density gradient centrifugation on Ficoll-Paque (Pharmacia, Freiburg, Germany) and washed in PBS (56.8 $\mathrm{mM} \mathrm{Na}_{2} \mathrm{HPO}_{4}$, $\left.17.9 \mathrm{mM} \mathrm{KH}_{2} \mathrm{PO}_{4}, 75 \mathrm{mM} \mathrm{NaCl}\right)$. Cytospins were prepared on a cytospin-2 centrifuge (Shandon, Astmore, UK) at $130 \times g$, air dried, and stored at $-20^{\circ} \mathrm{C}$. To store material for later analysis tumor cells were resuspended in RPMI 1640 medium with 20\% FCS (GIBCO) and 10\% DMSO (Sigma Chemical Co.), frozen in $2-\mathrm{mL}$ aliqots, and stored in liquid nitrogen. For controls of antibody specificity, bone marrow cells from a healthy adult human donor were prepared in the same manner. Cells from a culture of hepatoma cell line Hep G2 (ATCC, Rockville, MD) were washed in PBS before cytocentrifugation.

Primary cell cultures. Fresh pieces from all tumors were finely minced and incubated with RPMI 1640 medium, 10\% FCS, and collagenase type B (200 U/mL; GIBCO) for $2 \mathrm{~h}$ under sterile conditions. Cell suspensions were washed and cultured with RPMI 1640 medium containing 10\% FCS (GIBCO) in $25-\mathrm{cm}^{2}$ plastic flasks (Nunc, Wiesbaden, Germany). Supernatants were collected after $72 \mathrm{~h}$, cleared by centrifugation, and stored at $-20^{\circ} \mathrm{C}$. After outgrowth of tumor cells, these were detached with trypsin-EDTA (GIBCO) and in part used for preparation of cytospins, whereas other cells were recultured in identical conditions as previously described.

Antibodies. Mouse MAb were obtained from the following sources: Erythrocyte membrane K- (clone BS 45), M- (clone BS 57), and $\mathrm{N}$-antigens (clone BS 42; Biotest Pharma, Dreieich, Germany); anti-leukocyte common antigen CD45 (clone BMA 10; Behringwerke, Marburg, Germany), antithrombocyte membrane CD31 (clone BAG 85D10) and CD41 (clone BAG 75E5), anti-granulocyte precursor cells CD33 (clone 3W246) and CD34 (clone TUEK 3), anti-monocyte/ macrophage CD14 (clone TUEK 4), anti-T cells CD7 (clone VIPCD7), anti-B cells CD19 (clone B4) (all generously provided by Dr. M. R. Hadam, Medical School Hannover, Germany); anti-IL-3 (clone BO 282, Genzyme, Boston, MA); anti-G-CSF (clone Ab-1, Dianova, Hamburg, Germany); antiGM-CSF (clone BW 699/779, gift from Dr. R. Kurrle, Behringwerke, Marburg, Germany); anti-LIF (clone 8B11, kindly provided by M. Huang, Medical School Hannover, Germany) and anti-SCF (clones 4B10, 8G11, and 10E5, generated in our laboratory) (13), anti-cytokeratin (CK 1, clone LP34, Dakopatts, Copenhagen, Denmark; and clone Lu-5, Boehringer, Mannheim, Germany), anti-vimentin (clone V9[1], Dakopatts). Polyclonal rabbit antibodies were from the following sources: anti-M-CSF (BL-MCP, Genzyme), anti-EPO (Ka10, kindly provided by Dr. I. Rich, Ulm, Germany).

Immunochemistry. Cryostat sections and cytospins were stained using the APAAP technique essentially as previously described (14). Briefly, slides were thawed while still wrapped in aluminum foil, fixed in ice-cold acetone for $10 \mathrm{~min}$, and preincubated in normal rabbit serum (1:20) for staining with MAb and in normal human serum (1:20) for polyclonal anti- 
bodies for $10 \mathrm{~min}$. Twenty-five microliters of MAb or polyclonal rabbit antibody then were applied at a pretested dilution for $1 \mathrm{~h}$. Thereafter the slides were washed in Tris buffer $(0.2 \mathrm{M}$, $\mathrm{pH}$ 7.4) three times. In case of rabbit primary antibodies, this was followed by an incubation with polyclonal mouse-antirabbit Ig-serum (1:1000) (Jackson Immunoresearch Laboratories, West Grove, PA) for $1 \mathrm{~h}$. These slides were then covered with normal rabbit serum for $20 \mathrm{~min}$ after thorough washing. All slides were then incubated with rabbit anti-mouse Ig-serum (Dakopatts) (1:500) for $1 \mathrm{~h}$, followed by APAAP complex (Dakopatts) (1:100) for $1 \mathrm{~h}$. Incubation with the latter two reagents was repeated once for staining cryostat slides and twice for cytospins for $30 \mathrm{~min}$. Thereafter slides were washed with Tris buffer $\left(0.2 \mathrm{M}, \mathrm{pH} 9.2\right.$, containing $1 \mathrm{mM} \mathrm{MgCl}_{2}$ and $1 \mathrm{mM} \mathrm{ZnCl}_{2}$ ) for activation of alkaline phosphatase. For detection of immunostaining, the following solution was freshly prepared: $20 \mathrm{~mL}$ of $0.2 \mathrm{M}$ Tris buffer, $\mathrm{pH} 9.2$, with 1 $\mathrm{mM} \mathrm{MgCl}{ }_{2}$ and $1 \mathrm{mM} \mathrm{ZnCl}_{2}$ was mixed with $20 \mu \mathrm{L}$ of $1 \mathrm{M}$ levamisole (Sigma Chemical Co.) and $5 \mathrm{mg}$ naphthol-ASbiphosphate (Sigma Chemical Co.) in $100 \mu \mathrm{L}$ dimethylformamide (Merck, Darmstadt, Germany). Then $250 \mu \mathrm{L}$ of new fuchsin (Merck; $366 \mathrm{mg}$ dissolved in $25 \mathrm{~mL}$ of $2 \mathrm{~N} \mathrm{HCl}$ ) were added, and the solution was diazotized with $250 \mu \mathrm{L}$ of $0.6 \mathrm{M}$ $\mathrm{NaNO}_{2}$ (Merck). Slides were incubated with this solution for $30 \mathrm{~min}$. The reaction was stopped by rinsing with deionized water, followed by counterstaining in haemalaun (Merck) for $45 \mathrm{~s}$. The slides were again rinsed in water, air dried, and mounted with glycerol gelatin (Merck). Positive reaction resulted in bright red cytoplasmatic staining, whereas nuclei were counterstained blue. For negative control the same reaction without application of the primary antibody was performed on corresponding slides of all cryostats and cytospins.

Double immunostaining for EPO and SCF. Cytospin preparations of the HB were investigated by double immunofluorescence staining using as primary antibodies a polyclonal rabbit antibody against EPO, a murine anti-SCF IgA-MAb (10E5), and a IgG-MAb against cytokeratins (Lu-5), respectively, to localize the two cytokines to the epithelial HB cells. As secondary antibodies we used species- and subclass-specific antisera directed against Ig from rabbit and mouse that were conjugated with FITC or Texas Red, respectively. Anti-rabbitIg-FITC and anti-mouse-IgG-Texas Red were purchased from Vector Laboratories (Burlingame, CA), and anti-mouse-IgAFITC from Sigma Chemical Co. The antibodies were used in a concentration of $5 \mu \mathrm{g} / \mathrm{mL}$. The double-staining was photographed with an Olympus fluorescence microscope equipped with filter units for FITC and Texas Red.

Lysis of $\mathbf{H B}$ cells. For control of immunostaining and for determination of EPO in HB cells, frozen cells of tumors nos. $1,2,6,7$, and 10-15, and cells from tumor cell line Hep G2 were thawed, suspended in PBS, and the total amount of vital cells of each sample was determined by trypan blue exclusion. After centrifugation for $30 \mathrm{~min}$, ice-cold lysis buffer consisting of PBS with $1 \%$ Nonidet P-40 (Sigma Chemical Co.) was added to cell pellets $\left(2 \mu \mathrm{L} / 10^{4}\right.$ cells). Cells' nuclei and debris were removed by centrifugation at $13000 \times g$ for $10 \mathrm{~min}$. The supernatants were diluted with PBS, so that $1 \mathrm{~mL}$ of solution corresponded to $10^{6}$ cells.
Analysis for cytokines. Supernatants of primary HB cultures were analyzed for IL-3, LIF, G-CSF, and GM-CSF with ELISA test kits (British Biotechnology, Oxford, UK). ELISA for EPO was performed using a commercially available test kit (Medac, Hamburg, Germany) on supernatants of primary HB cultures, of a culture of tumor cell line Hep G2, and lysates of HB cells from tumor nos. 1,2, 6, 7, and 10-15. SCF was tested in a newly established sandwich-ELISA (15). Patients' sera and control sera from healthy children of the same age were analyzed for IL-3, SCF, LIF, G-CSF, and EPO. The commercially obtained ELISA assays were used according to the manufacturers' instructions. All measurements were performed at least in duplicate. Sensitivity of the tests was $32 \mathrm{pg} / \mathrm{mL}$ for IL-3 and LIF, $25 \mathrm{pg} / \mathrm{mL}$ for SCF, $78 \mathrm{pg} / \mathrm{mL}$ for G-CSF, 15 $\mathrm{pg} / \mathrm{mL}$ for GM-CSF, and $0.6 \mathrm{IU} / \mathrm{mL}$ for EPO.

Determination of M-CSF with immunoblot. For determination of M-CSF in $\mathrm{HB}$ cultures an immuno-dot-blot was performed essentially as described elsewhere (16). Briefly, 5 $\mu \mathrm{L}$ of supernatants from culture nos. $2,4,5,6,10,11,14$, and 15, various dilutions of rhM-CSF ( $\alpha$ Therapeutics, Los Angeles, CA), and control medium were blotted onto strips of nitrocellulose filter (Millipore, Eschborn, Germany) and airdried. After preincubation with Tris buffer (50 mM, pH 7.4) containing 3\% milk powder and $0.05 \%$ Tween 20 (Sigma Chemical Co.) for $30 \mathrm{~min}$, the strips were incubated with anti-M-CSF antibody (1:5000) for $1 \mathrm{~h}$ at $37^{\circ} \mathrm{C}$. After washing three times with Tris buffer, the filters were covered with mouse anti-rabbit Ig-serum (1:1000). For visualizing APAAP staining (14) was performed on the filters according to the above description. For development the filters were incubated in Tris buffer $\left(0.2 \mathrm{M}, \mathrm{pH} 9.2\right.$, containing $1 \mathrm{mM} \mathrm{MgCl}_{2}$ and 1 $\mathrm{mM} \mathrm{ZnCl}$ ) with nitro blue tetrazolium (Sigma Chemical Co.) $(0.33 \mathrm{mg} / \mathrm{mL})$ and 5-bromo-4-chloro-3-indolyl phosphate (Sigma Chemical Co.) $(0.17 \mathrm{mg} / \mathrm{mL}$ dimethylformamide) for 30 min. The reaction was stopped by washing the filters in $10 \mathrm{mM}$ Tris buffer, $\mathrm{pH} 7.5$, containing $1 \mathrm{mM}$ EDTA (Merck).

Western blot analysis of cellular extracts for SCF. Cells from $\mathrm{HB}$ nos. 1, 2, 6, 7, and 10-15 were washed three times with ice-cold PBS and lysed with $20 \mathrm{mM}$ Tris- $\mathrm{HCl}, \mathrm{pH} 7.4,50$ $\mathrm{mM} \mathrm{NaCl}, 1 \%$ Nonidet $\mathrm{P}-40$, containing $1 \mathrm{mM}$ phenylmethylsulfonyl fluoride, $1 \mathrm{mg} / \mathrm{mL}$ leupeptin (Boehringer), and 100 $\mathrm{U} / \mathrm{mL}$ aprotinin (Calbiochem, Bad Soden, Germany) for 30 min on ice. For $10^{7}$ cells, $1 \mathrm{~mL}$ of lysis buffer was used. Debris was removed by centrifugation for $10 \mathrm{~min}$ at $13000 \times g$ and $4^{\circ} \mathrm{C}$, and soluble proteins were separated by electrophoresis on $12 \%$ SDS-polyacrylamide gels. Proteins were blotted on nitrocellulose. After blocking with 5\% nonfat milk in PBS for $10 \mathrm{~h}$ at $4^{\circ} \mathrm{C}$, the filters were incubated with anti-SCF antibodies $8 \mathrm{G} 11$ and 10E5, respectively (1:1000 dilution of ascites). Binding of the primary antibody was detected by APAAP staining. The filters were developed using nitro blue tetrazolium/5-bromo-4-chloro-3-indolyl phosphate substrate (see above).

Proliferation assays for G-CSF and GM-CSF. For determination of bioactivity of G-CSF and GM-CSF in HB supernatants, proliferation assays using the G-CSF-dependent murine myeloblastic cell line NFS-60 (provided by Dr. W. Farrar, National Institutes of Health, Washington DC) and the GM- 
CSF-dependent human myeloid leukemia cell line GM/SO (gift of Dr. S. Oez, Nuremberg, Germany) were performed as described elsewhere $(17,18)$. Cells from these cell lines harvested in exponential growth were plated in a 96-well microtiter plate (Nunc) at a density of $10^{5} / \mathrm{mL}$ in RPMI 1640 medium with $10 \%$ FCS and various dilutions of the HB supernatants, recombinant human G-CSF or GM-CSF (Amgen, Thousand Oaks, CA), and medium controls respectively. After incubation for $48 \mathrm{~h}$ at $37^{\circ} \mathrm{C}$ the cells were exposed to 0.5 $\mu \mathrm{Ci}$ of $\left[{ }^{3} \mathrm{H}\right]$ thymidine (Amersham, Brunswick, Germany) per well for $4 \mathrm{~h}$ and then harvested onto glass-fiber strips. $\left[{ }^{3} \mathrm{H}\right]$ Thymidine incorporation was measured with a $2000 \mathrm{CA}$ Tri-carb liquid scintillation counter (Canberra Packard, Frankfurt, Germany), and the amounts of bioactive G-CSF or GM-CSF were calculated from the standard curves by probit analysis.

\section{RESULTS}

Eleven HB were purely epithelial, whereas four contained in addition mesenchymal elements and osteoid and were therefore classified as mixed HB. In 2 of the 15 tumors, the epithelial element consisted exclusivley of cells resembling fetal hepatocytes, whereas in two other cases, the epithelial component had a pure embryonal appearance. In the remaining tumors, the epithelial component displayed both fetal and embryonal differentiation with fetal cells predominating in seven cases and embryonal in four (Table 1). Hematopoiesis was detectable in all HB morphologically and immunohistochemically. Hematopoietic cells were arranged in typical foci in 11 tumors (Fig. 1) and were found dispersed throughout the tissue as single cells or in clusters of two to four cells in four tumors. They were usually located within sinusoids, but also occurred between epithelial tumor cells. Notably, in HB nos. 6 and 15 we found large numbers of hematopoietic cells between tumor cells of purely embryonal areas. Hematopoietic cells were not detected in mesenchymal tumor areas of the mixed HB. The majority of hematopoietic cells could be identified as erythroblasts (positive for BS 42 and in part also for BS 45 and BS 57) (Fig. 2). In embryonal areas the erythropoietic cells seemed not to be

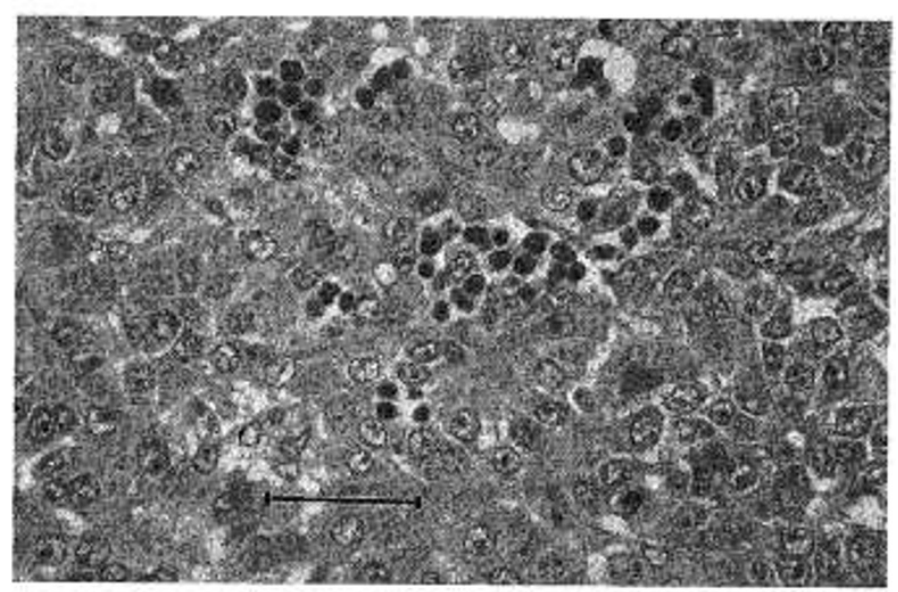

Figure 1. Erythropoietic focus in a fetal area of hepatoblastoma. Hematoxylin/eosin; bar $=50 \mu \mathrm{m}$.

arranged in such well defined foci as is found in fetal tissue. There was no correlation between the amount of erythroblasts and the differentiation of surrounding tumor cells. Histochemical staining revealed that the vast majority of erythroblasts did not contain $\mathrm{HbF}$, but interestingly, the relative proportion of $\mathrm{HbF}$-positive cells was larger in embryonal than in fetal tumor areas.

Megakaryocytes could be detected in $10 \mathrm{HB}$ and stained positive for CD31 and CD41. They were usually located separately from erythroblastic foci (Fig. 3). Single hematopoietic progenitor cells were stained with anti-CD34 MAb, which also reacted with endothelial cells. However, the density of these progenitor cells was low. Granulocyte precursor cells were not found, inasmuch as hematopoietic foci were negative for anti-CD33 MAb. This antibody and the anti-CD14 MAb identified single monocytes and macrophages disseminated throughout the tumor tissues. These cells as well as $\mathrm{CD} 7^{+} \mathrm{T}$ cells and to a lesser extent $\mathrm{CD} 19^{+} \mathrm{B}$ cells were increased in mixed $\mathrm{HB}$ and accummulated in necrotic areas but were not found in hematopoietic foci. Only in HB no. 15 a few large erythropoietic foci contained some monocytes. In contrast,

Table 1. Results of conventional histology and immunohistochemistry of $15 \mathrm{HB}$

\begin{tabular}{|c|c|c|c|c|c|c|}
\hline \multirow[b]{2}{*}{$\mathrm{HB}$} & \multirow[b]{2}{*}{ Histology } & \multirow[b]{2}{*}{ Hematopoiesis } & \multicolumn{4}{|c|}{ Hematopoietic cells } \\
\hline & & & Erybl. & Megak. & Gran.Prec. & Mono. \\
\hline 1 & Mixed, fet $>$ emb & Small foci & + & - & - & $+*$ \\
\hline 2 & Mixed, emb $>$ fet & Sparce foci & + & + & - & $+^{*}$ \\
\hline 3 & Mixed, emb $>$ fet & Numerous foci & + & + & - & $+*$ \\
\hline 4 & Epith, fet & Numerous foci & + & + & - & $(+)^{*}$ \\
\hline 5 & Mixed, fet $>$ emb & Sparce foci & + & + & - & $t^{*}$ \\
\hline 6 & Epith, emb & Dispersed single cells & + & + & - & $(+)^{*}$ \\
\hline 7 & Epith, emb & Sparce, single cells & + & - & - & $(+)^{*}$ \\
\hline 8 & Epith, fet & Numerous foci & + & + & - & $(+)^{*}$ \\
\hline 9 & Epith, fet $>$ emb & Sparce foci & + & + & - & $(+)^{*}$ \\
\hline 10 & Epith, fet $>$ emb & Sparce, single cells & + & - & - & - \\
\hline 11 & Epith, fet $>$ emb & Numerous foci & + & - & - & $(+)^{*}$ \\
\hline 12 & Epith, emb $>$ fet & Dispersed single cells & + & - & - & - \\
\hline 13 & Epith, fet $>$ emb & Sparce foci & + & + & - & $(+)^{*}$ \\
\hline 14 & Epith, fet $>\mathrm{emb}$ & Numerous foci & + & + & - & - \\
\hline 15 & Epith, emb > fet & Numerous foci & + & + & - & $(+)$ \\
\hline
\end{tabular}

Mixed $=$ mixed subtype, epith $=$ epithelial subtype, fet $=$ fetal areas, emb $=$ embryonal areas, erybl. $=$ erythroblasts, megak. $=$ megakaryocytes, gran.prec. $=$ granulocyte precursor cells, mono. $=$ monocytes; $+=$ detected,$(+)=$ rarely detected, $-=$ not detected, $*=$ monocytes not in foci. 


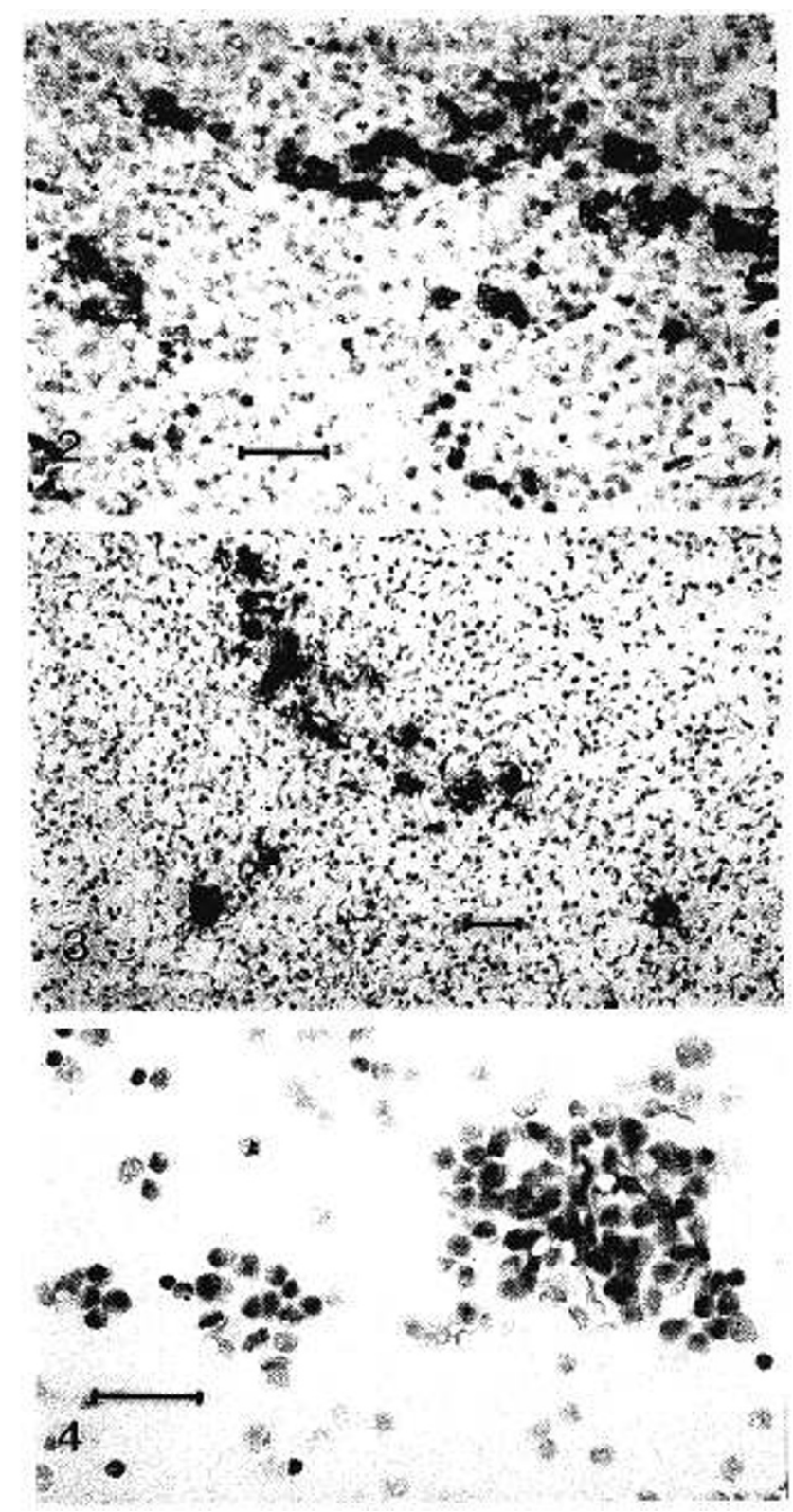

Figure 2. Immunohistochemical staining with MAb BS 42 identifying erythropoietic cells in a fetal hepatoblastoma. APAAP; bar $=50 \mu \mathrm{m}$.

Figure 3. Several megakaryocytes stained with anti-CD41 MAb surrounded by fetal hepatoblastoma tissue. APAAP; bar $=50 \mu \mathrm{m}$.

Figure 4. Immunostaining of a cytospin preparation of hepatoblastoma cells with rabbit polyclonal anti-EPO antibody demonstrating reactivity in the cytoplasm of tumor cells. APAAP; bar $=50 \mu \mathrm{m}$.

staining of fetal liver showed erythroblasts and megakaryocytes, but also granulocyte precursor cells and monocytes in sinusoids between trabecula of fetal hepatocytes. Hematopoiesis was not found in the patients' normal liver.

Immunohistochemistry for EPO and SCF showed a diffuse and weakly positive reaction in epithelial tumor areas of fetal and embryonal differentiation. In the nonneoplastic stroma of epithelial HB tissue, fibroblasts stained for G-CSF and also less intensively for SCF, GM-CSF, LIF, and M-CSF, whereas endothelial cells lining sinusoidal spaces and vessels were positive for G-CSF and M-CSF only. The reactivity of immature fibrous tissue which was the predominant mesenchymal tumor component of the mixed $\mathrm{HB}$ was identical to that of stromal fibroblasts. In contrast, single mesenchymal cells enclosed in osteoid and primitive spindle cells of one tumor expressed only G-CSF. IL-3 was found only in single leukocytes dispersed throughout the tumors. The hepatocytes of the patients' livers did not contain detectable amounts of cytokines. The negative controls on cryostat sections from all tumor and liver specimens did not show any staining.

All specimens were stained for cytokeratins and vimentin. Hepatocytes, bile duct epithelial cells, and all fetal and approximately $80 \%$ of embryonal tumor areas showed a strong reactivity with the anti-cytokeratin MAb and were negative for vimentin. In contrast, strong vimentin expression was observed in mesenchymal tissue of the liver (vessel walls, periportal fields), in the tumors' stroma (fibroblasts and endothelial cells), and in mesenchymal areas of mixed HB. Distribution of erythrocytes, platelets, leukocytes, and Kupffer cells in liver tissue as well as mature blood cells and progenitor cells in bone marrow stained as controls confirmed the specificity of antibody reactions.

The histologic composition of the HB was reflected in cytospin preparations of $\mathrm{HB}$, in which anti-cytokeratin stained positive on $90 \%$ of fetal and $60 \%$ of embryonal tumor cells. In contrast, anti-vimentin was negative on HB cells but strongly positive on fibroblasts and endothelial cells and in primitive spindle cells from the mixed HB. Erythroblasts and monocytes were only sparce in these preparations, whereas megakaryocytes were not detectable. Staining of cell preparations from primary $\mathrm{HB}$ cultures showed that these cultures contained stromal cells (fibroblasts and endothelial cells) and leukocytes besides epithelial HB cells. All fetal and approximately 50\% of embryonal tumor cells showed granular staining in the cytoplasm for EPO (Fig. 4) and SCF. The tumor cells were negative for the other cytokines. IL-3, G-CSF, GM-CSF, SCF, LIF, and M-CSF were detected in different subpopulations of mesenchymal cells (fibroblasts, endothelial cells, leukocytes), whereas these were negative for EPO. Immunoreactivity of the different cell types on HB cytospins for cytokines is summarized in Table 2. Staining of cells from tumor cell line Hep G2 showed an identical pattern of reactivity in comparison to fetal HB cells with positive staining for EPO and SCF only. With double immunostaining on $\mathrm{HB}$ cytospins using fluorescent markers, EPO and SCF, respectively, were clearly identified in epithelial tumor cells which were also reactive for cytokeratins (Fig. 5).

By ELISA EPO could be detected in 11 of the $15 \mathrm{HB}$ culture supernatants, in 2 cultures in high amounts $(>80 \mathrm{mIU} / \mathrm{mL})$ (Table 3). Hep G2 cells also secreted EPO in culture (28 $\mathrm{mIU} / \mathrm{mL})$. EPO was measurable above detection limits in lysates from 5 of the 10 tumors and Hep G2 cells (0.6-1.5 mIU/10 ${ }^{6}$ cells, HB nos. $1,6,11,12$, and 14). SCF was found above detection limits in 7 of 11 primary HB cultures. Lysates from HB cell nos. 6, 13, 14, and 15 and Hep G2 cells also contained SCF of approximately $35-\mathrm{kD}$ molecular size as detected in Western blot analysis. The anti-SCF MAb 10E5 stained 50 - and $30-\mathrm{kD}$ proteins in the blots from HB cell nos. 7 and 10. The other cytokines were found in less than half of the examined conditioned media, namely IL-3 in 1 of 12 , LIF 
Table 2. Cellular distribution of hematopoietic cytokines in HB in APAAP staining on cytospin preparations from 10 previously untreated tumors

\begin{tabular}{|c|c|c|c|c|c|c|c|}
\hline Cell type & EPO & SCF & IL-3 & G-CSF & GM-CSF & $\overline{\mathrm{LIF}}$ & M-CSF \\
\hline HB cells & $+^{*}$ & $+*$ & - & - & - & - & - \\
\hline Fibroblasts & - & ++ & - & +++ & + & ++ & + \\
\hline Endothelial cells & - & - & - & + & - & - & + \\
\hline Leukocytes & - & + & + & + & + & + & + \\
\hline Primitive spindle cells & - & - & - & + & - & - & - \\
\hline
\end{tabular}

$-=$ negative,$+=$ weak,$++=$ moderate,$+++=$ strong; $*=$ all fetal and approximately $50 \%$ of embryonal HB cells.

in 1 of 9 , GM-CSF in 4 of 9 , and G-CSF in none. The supernatant of the Hep G2 culture was also negative for LIF. In bioassays G-CSF could be detected in 4 (3 of these were not tested with ELISA) and GM-CSF in 3 of the 15 cultures. Yet GM-CSF was not detected in three supernatants which were positive with ELISA technique. In one supernatant G-CSF was slightly positive in bioassay but not detectable with ELISA. One of eight conditioned media was positive for M-CSF when examined by immunoblot (approximately $20 \mathrm{pg} / \mathrm{mL}$ ).

Ten patients were long-term survivors (3-5 y) without evidence of disease (six after primary and four after delayed tumor resection), whereas five died from recurrent tumor or metastatic disease. Initial hematologic examinations revealed platelet counts of $>1,000,000 / \mu \mathrm{L}$ in patient nos. 1,2 , and 4 and of $450000-999000 / \mu \mathrm{L}$ in patient nos. 3,5 , and 7-14, whereas platelet counts were normal in patient nos. 6 and 15. Fourteen children had a moderate, normochromic anemia. No patient had polycythemia or leukocytosis, and differential blood cell counts were not alterated. Pretreatment serum levels of EPO,
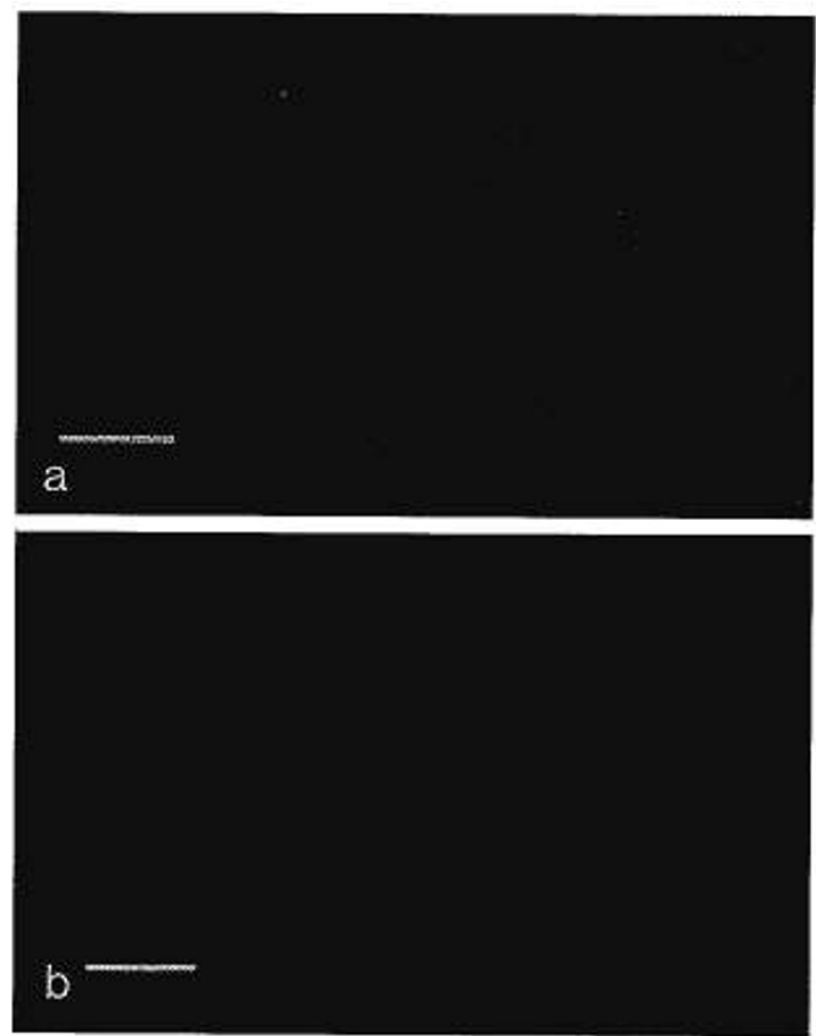

Figure 5. Double immunostaining of the same hepatoblastoma cells with anti-SCF MAb 10E5 ( $a$, green) and anti-cytokeratin MAb $(b$, red) in fluorescence microscopy. Bar $=50 \mu \mathrm{m}$.
G-CSF, IL-3, and LIF were not elevated in any of the patients compared with controls. There was no correlation between the patients' platelet counts, the amount of hematopoiesis in the tumors, and their cytokine production. These findings as well as the occurrence of extramedullary hematopoiesis and intratumoral cytokine production were not related to the patients' clinical course.

\section{DISCUSSION}

HB is an embryonal malignancy of the liver that almost exclusively affects very young children (12). Morphologically, the epithelial tumor components resemble either embryonal or fetal liver tissue (1). Because the liver is the major site of fetal hematopoiesis, it is not surprising to find hematopoietic nests in HB. Hematopiesis has long been associated with areas of fetal differentiation $(1,4)$, but was also reported to occur in embryonal tumor areas (2). In this series we found hematopoiesis in all $15 \mathrm{HB}$ studied. Hematopoietic cells were detectable even in pure embryonal tumors, although the latter lacked the typical arrangement in discrete foci (Table 1). As in fetal liver (3), hematopoietic cells in $\mathrm{HB}$ can be found either in sinusoidal spaces or directly between epithelial tumor cells (4). Interestingly, in $\mathrm{HB}$ erythroblasts usually do not contain $\mathrm{HbF}$. Although we were able to demonstrate erythropoietic cells and megakaryocytes, we were unable to detect granulocyte or monocyte precursor cells in hematopoietic nests. This confirms results of studies with conventional histologic techniques (1, 2). In contrast, embryonal hematopoiesis in the fetal liver also comprises the formation of macrophages during early gestation (6th wk), whereas granulopoiesis occurs after the 16th wk of gestation $(19,20)$. In HB the local microenvironment seem's to be suited only for the induction of erythropoiesis and megakaryopoiesis. Although intensive erythropoiesis is sometimes found throughout the tumors, it does not seem to contribute much to the peripheral blood cell pool, because even children with a large tumor do not have an elevated hematocrit.

The origin of hematopoietic cells in HB is still unknown. It seems unlikely that $\mathrm{HB}$ cells themselves undergo a transition to hematopoietic stem cells, because they are clearly differentiated as epithelial cells (21). In xenotransplanted HB, we found that intratumoral hematopoiesis progressively decreases and disappears during serial grafting of tumors but sometimes reappears after transplantation of $\mathrm{HB}$ cells together with fibroblasts (our unpublished experiments). It is conceivable that hematopoietic stem cells that migrate from the yolk sac to the liver in early fetal life $(19,20)$ could be preserved in the suitable environment of transformed fetal liver tissue, which 
Table 3. Levels of hematopoietic cytokines in supernatants of primary HB cell cultures measured by ELISA, immunoblot, and bioassay

\begin{tabular}{|c|c|c|c|c|c|c|c|c|c|}
\hline \multirow[b]{2}{*}{ HB } & \multicolumn{6}{|c|}{ ELISA } & \multicolumn{2}{|c|}{ Bioassay } & \multirow[b]{2}{*}{$\begin{array}{r}\text { Blot } \\
\text { M-CSF }\end{array}$} \\
\hline & $\begin{array}{c}\text { EPO } \\
(\mathrm{mIU} / \mathrm{ml})\end{array}$ & $\begin{array}{c}\mathrm{SCF} \\
(\mathrm{pg} / \mathrm{ml})\end{array}$ & $\begin{array}{c}\mathrm{IL}-3 \\
(\mathrm{pg} / \mathrm{ml})\end{array}$ & $\begin{array}{c}\text { LIF } \\
(\mathrm{pg} / \mathrm{ml})\end{array}$ & $\begin{array}{l}\text { G-CSF } \\
(\mathrm{pg} / \mathrm{ml})\end{array}$ & $\begin{array}{c}\text { GM-CSF } \\
(\mathrm{pg} / \mathrm{ml}) \\
\end{array}$ & G-CSF & GM-CSF & \\
\hline 1 & 3.5 & NT & NT & NT & NT & NT & + & + & NT \\
\hline 2 & 0 & 0 & 0 & 0 & 0 & 32 & - & + & - \\
\hline 3 & 0 & NT & NT & NT & NT & NT & + & + & NT \\
\hline 4 & $>80.0$ & 0 & 0 & 0 & 0 & 50 & - & - & $t^{*}$ \\
\hline 5 & 3.6 & 76 & 0 & 0 & 0 & 0 & - & - & - \\
\hline 6 & 1.3 & 142 & 0 & 0 & 0 & 0 & - & - & - \\
\hline 7 & 8.2 & 0 & 0 & NT & NT & NT & - & - & NT \\
\hline 8 & 3.4 & NT & 0 & NT & NT & NT & + & - & NT \\
\hline 9 & $>80.0$ & 10700 & 1800 & 0 & 0 & 3437 & - & - & - \\
\hline 10 & 2.2 & 134 & 0 & 0 & 0 & 0 & - & - & - \\
\hline 11 & 0 & 0 & 0 & 124 & 0 & 48 & - & - & - \\
\hline 12 & 1.7 & 44 & 0 & NT & NT & NT & - & - & - \\
\hline 13 & 0 & 40 & 0 & NT & NT & NT & - & - & - \\
\hline 14 & 2.8 & 112 & 0 & 0 & 0 & 0 & + & - & - \\
\hline 15 & 37.0 & NT & NT & 0 & 0 & 0 & - & - & - \\
\hline
\end{tabular}

$0=<$ detection limit; NT $=$ not tested $+=$ detectable; $-=$ not detectable $; *$ approximately $20 \mathrm{pg} / \mathrm{ml}$.

may be the case for HB occurring during intrauterine life (22). However, most of the erythroblasts in $\mathrm{HB}$ seem to be too mature to form $\mathrm{HbF}$, and hematopoiesis also occurred in $\mathrm{HB}$ no. 15 of this series that was a recurrent tumor in the remaining liver $2 \mathrm{y}$ after resection and treatment with chemotherapy. Furthermore, hematopoiesis can rarely be found in hepatocellular carcinomas of children and adolescents (D. Harms, Central Pediatric Tumor Registry, Kiel, Germany, personal communication) and transiently appears in adult liver transplants (23). Finally, we found that cells from an HB cell line were able to induce hematopoiesis in a murine xenograft model (our manuscript in preparation). All of these observations suggest that $\mathrm{HB}$ tissue retains circulating $\mathrm{CD} 34^{+}$multipotential progenitors of bone marrow origin, which then proliferate and differentiate to more mature erythroblasts and megakaryocytes $(7,19)$.

Hematopoietic cytokines regulate hematopoiesis in a complex network of interactions (9). This also applies for hematopoiesis in the fetal liver (20). In a recent investigation we showed that $\mathrm{HB}$ cells can produce IL- $1 \beta$ and thereby enhance secretion of IL- 6 by stromal cells (8). However, the molecular mechanisms leading to the reappearance of fetal hematopoiesis in $\mathrm{HB}$ are not yet defined. Therefore, we now investigated the production of hematopoietic cytokines in this tumor. These include IL-3 and GM-CSF which induce the proliferation of myeloid progenitor cells (24), G-CSF, a promotor of granulopoiesis (25), M-CSF, a growth factor for macrophage progenitors (9), and LIF which stimulates megakaryopoiesis and increases the production of platelets (26). Furthermore, we were interested in determining whether we could detect EPO in HB. This cytokine stimulates erythropoiesis and perhaps megakaryopoiesis (27), and in the fetus it is produced in the liver (5). Finally, we studied the expression of SCF (11) in HB, because this cytokine acts on early progenitors of various lineages including erythropoiesis and megakaryopoiesis and is also known to affect hematopoietic cells in the fetal liver (7). It is remarkable that we could detect EPO and SCF in the cytoplasm of epithelial tumor cells by immunostaining, which was confirmed by examination of cellular extracts. We also found EPO in 11 of $15 \mathrm{HB}$ cultures. This is consistent with the finding that two hepatoma cell lines (Hep G2 and Hep 3B) secrete EPO (6), which we could confirm for Hep G2. Hence, in fetal liver this factor might not be only produced by macrophages (28) but also by fetal hepatocytes (19). Interestingly, EPO production in Hep $3 \mathrm{~B}$ cells is stimulated by IL-6 but impeded by IL-1 $\beta$ (29) which were both detected in HB (8). Although it was shown that SCF has an important function in the stimulation of multipotential hematopoietic cells in fetal liver (7), the site of its production in the liver is unknown. In this study, we were able to localize SCF to the cytoplasm of HB cells in all tumors as well as in 7 of 11 tumor cultures. SCF not only promotes erythropoiesis in neonates (30), but also influences erythropoiesis (31) and megakaryopoiesis (32) of adult bone marrow and synergizes with most of the other investigated cytokines (31). It therefore seems to be an essential factor in fetal hematopoiesis $(7,33)$. IL-3 is an important factor for stimulation of multipotential progenitor cells (34) and may also act as a cofactor in fetal hematopoiesis (33). However, we could detect this factor only in leukocytes, and only one (HB no. 9) of the conditioned media contained IL-3. The cell population of this culture consisted of $70 \%$ mesenchymal cells including multiple leukocytes and only $30 \%$ of epithelial tumor cells and secreted also EPO, SCF, and GMCSF in high levels (Table 3). The finding of G-CSF by bioassay of one supernatant which was negative by ELISA is most likely due to the higher sensitivity of the former test system. Because GM-CSF was detected only by ELISA but not by bioassay in these supernatants, we suspect inhibitory substance(s) to be produced in these cultures as well. This discrepancy was not seen in the other $\mathrm{HB}$ cultures.

Our results of immunostaining show that G-CSF, GM-CSF, M-CSF, and LIF are not produced by epithelial tumor cells in HB but rather by mesenchymal stromal cells and fibrous tumor tissue in mixed HB probably through the effect of inducers such as IL-1 $\beta$ (35). These factors were well detectable in these cells which especially accounts for G-CSF. This was expected, 
as it is well known that mature fibroblasts and endothelial cells (9) as well as immature fibroblastoid cells from the fetal liver (36) produce these factors. Thus, stromal cells may also influence HB cells with respect to secretion of the identified cytokines. Lymphocytes in the stroma could also contribute to the production of these growth factors, but they were not found in hematopoietic areas and do not play a substantial role in hematopoiesis of the fetal liver (19). Because the fraction of mesenchymal cells was small in the cell cultures, these cytokines were not regularily found in the supernatants. Alternatively, secretion of these cytokines by stromal cells may be blocked by inhibitory factors leading to cytoplasmatic staining by immunohistochemistry without detectable levels in the cell culture supernatants. This would also explain the absence of granulopoiesis in $\mathrm{Hb}$. One inhibitory factor may be EPO which was reported to suppress neutrophil production in human hematopoietic clones (37).

The investigated hematopoietic cytokines are only one component of the microenvironment of $\mathrm{HB}$ tissue. The extracellular matrix proteins such as fibronectin and laminin that were found in HB (38) may be of importance for the homing of erythropoietic and megakaryopoietic cells. Furthermore, we recently found different adhesion molecules, in particular ICAM-1 (CD54), VCAM-1, and ELAM-1 to be strongly expressed in epithelial HB tissue (our manuscript submitted for publication). Their contribution to local formation of hematopoiesis still has to be elucidated.

We conclude that epithelial HB cells express EPO, SCF, and IL- $1 \beta$. In addition they are able to initiate the production of other hematopoietic cytokines such as IL-6 (8) and probably also G-CSF, GM-CSF, M-CSF, and LIF in stromal cells by paracrine stimulation. The role of these "secondary" cytokines remains unclear, because we found only erythropoiesis and megakaryopoiesis in HB. Erythropoiesis may be supported by the local secretion of EPO and SCF of the tumor cells. However, although SCF, LIF, and IL-6 can contribute to megakaryopoiesis, it is still possible that an additional megakaryopoietic factor(s) such as the recently cloned c-Mpl ligand (39) that has mega-CSF activity and is produced in fetal liver is expressed in HB. This hypothesis is supported by the fact that only a subgroup of HB displays megakaryopoiesis. The absence of other lineages may be caused by the lack of their progenitors, insufficient concentrations of supporting cytokines or the presence of specific inhibitors (37). Except for IL-6 which is related to thrombocytosis and fever in children with $\mathrm{HB}(8)$ all other cytokines are only locally active and do not have systemic effects. Despite this fact, HB may be an interesting model for studies on the role of cytokines in fetal extramedullary hematopoiesis.

Acknowledgments. The authors thank Dr. M. R. Hadam (Medical School Hannover) for technical advice and for providing $\mathrm{MAb}$. Additional antibodies were generous gifts from Dr. R. Kurrle (Beringwerke, Marburg), M. Huang (Medical School Hannover), and from Dr. I. Rich (University of Ulm). The cell line NFS-60 was kindly donated by Dr. W. Farrar (National Institutes of Health, Washington D.C.) and the cell line GM/SO by Dr. S. Oez (Nuremberg). We thank A.
Hendricks, T. Scharmann, and D. Kajetanowicz (Medical School Hannover) for excellent technical assistance and Dr. S. Albrecht (University of Bonn) for critical reading of the manuscript.

\section{REFERENCES}

1. Ishak KG, Glunz PR 1967 Hepatoblastoma and hepatocarcinoma in infancy and childhood. Cancer 20:396-422

2. Schmidt D, Harms D, Lang W 1985 Primary malignant hepatic tumours in childhood. Virchows Arch Pathol Anat 407:387-405

3. Petti S, Testa U, Migliaccio AR, Mavilio F, Marinucci M, Lazzaro D, Russo G, Mastroberardino G, Peschle C 1985 Embryonic hemopoiesis in human liver: morphologic aspects at sequential stages of ontogenic development. Prog Clin Biol Res 193:57-72

4. Emura I, Ohnishi Y, Yamashita Y, Iwafuchi M 1985 Immunohistochemical and ultrastructural study on erythropoiesis in hepatoblastoma. Acta Pathol Jpn 35:79-86

5. Flake AW, Harrison MR, Adzick NS, Zanjani ED 1987 Erythropoietin production by the fetal liver in an adult environment. Blood 70:542-545

6. Goldberg MA, Glass GA, Cunningham JM, Bunn HF 1987 The regulated expression of erythropoietin by two human hepatoma cell lines. Proc Natl Acad Sci USA 84:7972-7976

7. Papayannopoulou T, Brice M, Broudy VC, Zsebo KM 1991 Isolation of c-kit receptor-expressing cells from bone marrow, peripheral blood, and fetal liver: functional properties and composite antigenic profile. Blood 78:1403-1412

8. von Schweinitz D, Hadam MR, Welte K, Mildenberger H, Pietsch T 1993 Production of interleukin- $1 \beta$ and interleukin- 6 in hepatoblastoma. Int J Cancer 53:728-735

9. Metcalf D 1986 The molecular biology and functions of the granulocyte-macrophage colony-stimulating factors. Blood 67:257-267

10. Williams RL, Hilton DJ, Pease S, Willson TA, Stewart CL, Gearing DP, Wagner EF, Metcalf D, Nicola NA, Gough NM 1988 Myeloid leukaemia inhibitory factor maintains the developmental potential of embryonic stem cells. Nature 336:684-687

11. Matsui Y, Zsebo KM, Hogan LM 1990 Embryonic expression of a haematopoietic growth factor encoded by the SI locus and the ligand for c-kit. Nature 347:667-669

12. von Schweinitz D, Bürger D, Weinel P, Mildenberger H 1992 The treatment of malignant liver tumours in childhood. An interim report of the multicentric study HB89 of the GPOH. Klin Paediatr 204:214-220

13. Pietsch $T 1993$ Paracrine and autocrine growth mechanisms of human stem cell factor (c-kit ligand) in myeloid leukemia. Nouv Rev Fr Hematol 35:285-286

14. Cordell JL, Falini B, Erber WN, Ghosh AK, Abdulaziz Z, MacDonald S, Pulford KAF, Stein H, Mason DY 1984 Immunoenzymatic labelling of monoclonal antibodies using immune complexes of alkaline phosphatase and monoclonal anti-alkaline phosphatase (APAAP complexes). J Histochem Cytochem 32:219-229

15. Manegold C, Jablonowski H, Armbrecht C, Strohmeyer G, Pietsch T 1995 Serum levels of stem cell factor are increased in asymptomatic HIV-infected patients and associated with prolonged survival. Blood 86:243-249

16. Hawkes R, Niday E, Gordon J 1982 A dot-immunobinding assay for monoclonal and other antibodies. Anal Biochem 119:142-147

17. Pietsch T, Mempel K, Menzel T, Öckler R, Welte K 1990 Medulloblastoma cells constitutively produce granulocyte colony-stimulating factor. Klin Paediatr 202:235239

18. Pietsch T, Kyas U, Drexler HG, Welte K 1993 Human stem cell factor is a growth factor for myeloid leukemia cells. Recent Results Cancer Res 131:329-338

19. Christensen RD 1989 Hematopoiesis in the fetus and neonate. Pediatr Res 6:531-535

20. Tavassoli M 1991 Embryonic and fetal hemopoiesis: an overview. Blood Cells 1:269-281

21. Abenoza P, Manivel JC, Wick MR, Hagen K, Dehner LP 1987 Hepatoblastoma: an immunohistochemical and ultrastructural study. Hum Pathol 18:1025-1035

22. Kazzi NJ, Chang C-H, Roberts EC, Shankara S 1989 Fetal hepatoblastoma presenting as nonimmune hydrops. Am J Perinatol 6:278-280

23. Schlitt HJ, Schäfers S, Deiwick A, Eckardt K-U, Pietsch T, Ebell W, Nashan B, Ringe B, Wonigeit K, Pichlmayr R 1995 Extramedullary erythropoiesis in human liver grafts. Hepatology 21:689-696

24. Sonoda Y, Yang Y-C, Wong GG, Clark SC, Ogawa M 1988 Analysis in serum-free culture of the targets of recombinant human hemopoietic growth factors: interleukin-3 and granulocyte/macrophage-colony-stimulating factor are specific for early developmental stage. Proc Natl Acad Sci USA 85:4360-4364

25. Welte K, Bonilla MA, Gillio AP, Boone TC, Potter K, Gabrilove JL, Moore MAS, O'Reilly RJ, Souza LM 1987 Recombinant human G-CSF: effects on hematopoiesis in normal and cyclophosphamide treated primates. J Exp Med 165:941-948

26. Metcalf D, Nicola NA, Gearing DP 1990 Effects of injected leukemia inhibitory factor on hematopoietic and other tissues in mice. Blood 76:50-56

27. Berridge MV, Fraser JK, Carter JM, Lin F-K 1988 Effects of recombinant human erythropoietin on megakaryocytes and on platelet production in the rat. Blood 72:970-977

28. Ohls RK, Li Y, Trautman MS, Christensen RD 1994 Erythropoietin production by macrophages from preterm infants: implications regarding the cause of the anemia of prematurity. Pediatr Res 35:169-170

29. Faquin WC, Schneider TJ, Goldberg MA 1992 Effect of inflammatory cytokines on hypoxia-induced erythropoietin production. Blood 79:1987-1994

30. Weinberg RS, Thompson JC, Lao R, Chen G, Alter BP 1993 Stem cell factor amplifies newborn and sickle erythropoiesis in liquid cultures. Blood 81:2591-2599 
31. McNiece IK, Langley KE, Zsebo KM 1991 Recombinant human stem cell factor synergises with GM-CSF, G-CSF, IL-3 and Epo to stimulate human progenitor cells of the myeloid and erythroid lineages. Exp Hematol 19:226-231

32. Avraham H, Vannier E, Cowley S, Jiang S, Dinarello CA, Zsebo KM, Groopman JE 1992 Effects of the stem cell factor, c-kit ligand, on human megakaryocytic cells. Blood 79:365-371

33. Yu H, Bauer B, Lopke GK, Phillips RL, Van Zant G 1993 Apoptosis and hematopoiesis in murine fetal liver. Blood 81:373-384

34. Ottmann OG, Ganser A, Seipelt G, Eder M, Schulz G, Hoelzer D 1990 Effects of recombinant human interleukin-3 on human hematopoietic progenitor and precursor cells in vivo. Blood 76:1494-1502

35. Sieff CA, Niemeyer CM, Mentzer SJ, Faller DV 1988 Interleukin-1, tumor necrosis factor, and the production of colony-stimulating factors by cultured mesenchymal cells. Blood 72:1316-1323

36. Tsai S, Emerson SG, Sieff CA, Nathan DG 1986 Isolation of a human stromal cell strain secreting hemopoietic growth factors. J Cell Physiol 127:137-145

37. Christensen RD, Koenig JM, Viskochil DH, Rothstein G 1989 Down-modulation of neutrophil production by erythropoietin in human hematopoietic clones. Blood 74:817-822

38. Ruck P, Kaiserling E 1992 Extracellular matrix in hepatoblastoma: an immunohistochemical investigation. Histopathology 21:115-126

39. de Sauvage FJ, Hass PE, Spencer SD, Malloy BE, Gurney AL, Spencer SA, Darbonne WC, Henzel WJ, Wong SC, Kuang W-J, Oles KJ, Hultgren B, Solberg LA, Goeddel DV, Eaton DL 1994 Stimulation of megakaryopoiesis and thrombopoiesis by the c-Mpl ligand. Nature 369:533-538 